\title{
Seroprevalence of HIV \& HCV coinfection among patients in a rural tertiary care centre in North India
}

\author{
Kaur C. \\ ${ }^{1}$ Assistant Professor, Sri Guru Ram Das Institute of Medical Sciences and Research, Amritsar, Punjab, India \\ Dr. Charanjeev Kaur, Assistant Professor, Sri Guru Ram Das Institute of Medical Sciences and Research, Amritsar, \\ Punjab, India.
}

Corresponding Author: Dr. Charanjeev Kaur, Assistant Professor, Sri Guru Ram Das Institute of Medical Sciences and Research, Amritsar, Punjab, India. E-mail: drcharanjeev@gmail.com

\begin{abstract}
Objective: Viral hepatitis $\mathrm{C}$ infection is associated with high morbidity and mortality rates. Chronic HCV infection can cause a wide spectrum of liver disease, potentially leading to severe liver damage, including cirrhosis, organ failure and hepatocellular carcinoma. It accounts for nearly $12-32 \%$ of all cases of liver cancer and $10-20 \%$ cases of cirrhosis of liver, both of which have high treatment costs and poor outcomes. As route of infection of Human Immunodeficiency Virus, Hepatitis B Virus (HBV) and the Hepatitis C Virus (HCV) is same, People with HIV infection are at more risk of acquiring Hepatitis B Virus (HBV) and the Hepatitis C Virus (HCV) infection. The co-infection of Hepatitis C virus with HIV accelerates disease progression and also has an effect on the management of patients infected with HIV. The prevalence of HIV co-infection with Hepatitis $\mathrm{C}$ virus varies widely. This study is planned to evaluate the prevalence of HIV co-infection with Hepatitis C viruses in North India. Materials and Methods: A total of 25443 patients enrolled in the microbiology lab were retrospectively analyzed for the presence of HCV and HIV infection on the basis of the presence of anti-HCV and anti HIV markers. Results: In patients infected with HIV, the prevalence of co-infection with $\mathrm{HCV}$ was $0.07 \%$. The mean age of the study group was 28.7 years. Discussion: The prevalence rate of HCV are increasing in patients infected with HIV. Having acquired the knowledge about the importance of such a co-infection, it is essential that all the patients infected with HIV be screened for HCV co-infection.
\end{abstract}

Keywords: HIV, HCV, Seroprevalence, Co-infection

\section{Introduction}

Hepatitis $\mathrm{C}$ virus (HCV) is a single-stranded RNA virus. Viral hepatitis $\mathrm{C}$ infection is associated with high morbidity and mortality rates. Chronic $\mathrm{HCV}$ infection can cause a wide spectrum of liver disease, potentially leading to severe liver damage, including cirrhosis, organ failure and hepatocellular carcinoma. It accounts for nearly $12-32 \%$ of all cases of liver cancer and 10 $20 \%$ cases of cirrhosis of liver, both of which have high treatment costs and poor outcomes [1].

As route of infection of Human Immunodeficiency Virus, Hepatitis B Virus (HBV) and the Hepatitis C Virus (HCV) is same, People with HIV infection are at more risk of acquiring Hepatitis B Virus (HBV) and the Hepatitis C Virus (HCV) infection. The epidemiological parameters of these viruses are quite similar, like routes of transmission, there associated risk factors and the

Manuscript received: $14^{\text {th }}$ November 2018

Reviewed: $24^{\text {th }}$ November 2018

Author Corrected: $30^{\text {th }}$ November 2018

Accepted for Publication: $5^{\text {th }}$ December 2018 presence of these viruses in various body fluids [2]. With increased availability of antibiotics and antifungal drugs, HBV and $\mathrm{HCV}$ infection are becoming a cause for significant concern for individuals infected with HIV. The co-infection of HCV with HIV is associated with a loss of immunological control of HCV thus leading to rapid progression of HCV disease [3]. In coinfection, one virus affects the life cycle of the other virus which is present simultaneously in the same host.

Persons who inject drugs (PWID) are at highest risk of acquiring HIV and HCV coinfection as these viruses have same route of infection. $\mathrm{HCV}$ is 10 times more infectious than HIV through percutaneous blood exposures. Other high-risk factors of HIV and HCV coinfection are people who take injections, people who are immunocompromised, vertical transmission from infected mother to child. People with HCV infected sexual partners. People with HIV infection, in particular $\mathrm{MSM}$, are at higher risk of $\mathrm{HCV}$ infection trough

Pathology Update: Tropical Journal of Pathology \& Microbiology Available online at: www.pathologyreview.in 617 | P a g e 
unprotected sex. Tattoo recipients are also at higher risk of acquiring $\mathrm{HCV}$ infection. Out of total population of PWID, 67\% are infected with HCV worldwide. [4] Transmission through blood transfusions is rare now a days due to rapid and regular screening of blood and blood products Of the estimated 36.7 million people living with HIV globally, around 2.3 million have past or present $\mathrm{HCV}$ infection, and of those, around 1.36 million are people who inject drugs [4].

In HIV coinfection with HCV, HIV accelerates the natural course of $\mathrm{HCV}$ infection, leading to faster progression of liver disease to cirrhosis finally causing hepatocellular carcinoma.

Anti-retroviral therapy has led to decline in death rate due to AIDS but liver diseases caused by HCV coinfection are one of the major cause of non AIDS related deaths of HIV patients.[5]

Universal screening of Hepatitis C in HIV infected patients is highly recommended for the treatment purpose. First the patient should be checked for HCV antibodies. If antibodies are positive then confirm the presence of $\mathrm{HCV}$ in patients' blood. Positive result confirms the presence of $\mathrm{HCV}$. [fact sheet]

The present study was conducted to detect the current seroprevalence of HCV co-infection in patients infected with HIV in a Rural Tertiary Care hospital in North India.

\section{Material and Methods:}

Study design: Prospective study

Study site: Microbiology laboratory of SGRDIMSR, Amritsar.

Duration of study: November 2017 to October 2018

\section{Original Research Article}

\section{Inclusion criteria}

Patients with clinical history and signs and symptoms suggestive of an immuno-compromised condition pre-operative patients

Antenatal patients

Exclusion criteria: Patients who were seronegative for HIV or HCV

Sample collection: $5 \mathrm{ml}$ of blood sample collected using a sterile plain vacutainer, under all aseptic precautions.

Sample processing: $5 \mathrm{ml}$ blood was collected in a clean dry sterile vial and allowed to clot or serum separated by centrifugation at room temperature. If serum isnot to be assayed immediately then stored at $2-8^{\circ} \mathrm{C}$ or frozen at minus $20^{\circ} \mathrm{C}\left(-20^{\circ} \mathrm{C}\right)$.

The marker used for screening of HIV was antibodies to HIV-1 \& HIV-2 and was detected by one rapid test and a solid phase enzyme linked immunosorbant assay (ELISA), which was based on direct sandwich principle (HEPALISA- manufactured by J. Mitra and co Pvt Ltd).

For $\mathrm{HCV}$, one rapid test and anti $\mathrm{HCV}$ (IgG) ELISA was done using 3rd generation ELISA kit (HCV Microelisa by J. Mitra and co pvt Ltd). For HIV tri-dot rapid visual test for the qualitative detection of antibodies to HIV-1 \& HIV-2 in human serum/plasma used. (Diagnostic enterprises) HCV tri-dot rapid visual test for the qualitative detection of antibodies to Hepatitis $\mathrm{C}$ virus in human serum/plasma was used. (Diagnostic enterprises).

The tests were performed as per the manufacturer's instructions. ELISA test was done as per the manufacturer's instructions along with validity check and incorporation of internal controls.

\section{Results}

The present study received total 25443 samples in the microbiology lab for HIV and HCV detection together. Out of these 9136 presented for HIV detection. Total HIV positive patients were $0.73 \%(67)$. Total patients presented for HCV detection were 16307 . Out of these $3.23 \%$ (527) patients were reactive for HCV. The prevalence of HCV coinfection with HIV was $0.07 \%$ (19)

Table No-1: Prevalence of $\mathrm{HCV}$ in HIV reactive patients.

\begin{tabular}{|l|c|c|}
\hline Samples received & Tested & Reactive \\
\hline FOR HIV & 9136 & $67(0.73 \%)$ \\
\hline FOR HCV & 16307 & $527(3.23 \%)$ \\
\hline Total (HIV+HCV) & $\mathbf{2 5 4 3 3}$ & $\mathbf{1 9 ( 0 . 0 7 \% )}$ \\
\hline
\end{tabular}

Pathology Update: Tropical Journal of Pathology \& Microbiology Available online at: www.pathologyreview.in 618 | P a g e 


\section{Original Research Article}

Table No-2: The distribution of HIV+HCV co-infection by age and gender in the study group

\begin{tabular}{|c|c|c|}
\hline Age & Male & Female \\
\hline$<10$ & 1 & 0 \\
\hline $10-20$ & 0 & 0 \\
\hline $20-30$ & 10 & 0 \\
\hline $30-40$ & 01 & 1 \\
\hline $40-50$ & 02 & 1 \\
\hline $50-60$ & 02 & 0 \\
\hline $60-75$ & 01 & 0 \\
\hline Total & $\mathbf{1 7}$ & $\mathbf{2}$ \\
\hline
\end{tabular}

The mean age of the study group was 28.7 years.

\section{Discussion}

India has the third largest number of individuals with HIV after South Africa and Nigeria [6]. Coinfection of HIV with the HCV is a common event due to similar route of transmission [6]. India which contributes significantly to the global $\mathrm{HCV}$ burden, is believed to harbour 12-18 million HCV-infected people. The estimated prevalence of $\mathrm{HCV}$ in India is $0.5 \%-1.5 \%$ [7].

All the HIV positive patients should be screened for HCV coinfection. HCV antibodies appear between six weeks to six months of infection. Screening is done with anti $\mathrm{HCV}$ elisa test.

It is noted in the present study that the age of the study group is 20-30 years, which is less as compared to previous studies from India [7] while in accordance with the study by Kalyani et al [3]. The mean age of the study group is 28.7 years which is slightly lower than that in the study by Ahuja et al. Thus, the younger population in the economically productive age group is being increasingly affected by HIV, leading to a loss to the economy. This could be because of the increased exposure of this population to the risk factors like promiscuity, parenteral drug abuse, etc.

Among the patients presenting for treatment of either $\mathrm{HCV}$ or HIV infection, HIV \& HCV coinfection is emerging as important and more frequent finding. Similar route of transmission appears to be the most important factor for higher prevalence rate of coinfection. Coinfection with HCV leads to chronic liver damage in HIV patients and more than $15 \%$ developed severe liver damage or cirrhosis [8]. The present study shows that mainly male patients are infected, this is in accordance with previous study that shows male patients are at a higher risk of acquiring infection.
Present study reports HIV and HCV coinfection in $0.07 \%$ which is lesser than the study by Jain etal [1]. The HCV co infection in the study by Kalyani et al was $2 \%$, while Oslanisun, Olefemi, Adewole et al [9] reported 2.3\%. A study by Baveja et al has shown prevalence rate of $9.64 \%$ [10]. However, another study by Ponamagi et al shows that HIV infected patients are at a higher risk of coinfection as shown by the prevalence of $\mathrm{HCV}(3.02 \%)$ [8]. Prevalence rate among various cities in India is $2.3 \%$ in Chennai [11], $1.6 \%$ in Lucknow, whereas higher in Nagpur $7.2 \%, 8 \%$ from Mumbai and $8.3 \%$ from Hyderabad [3]. In another study from Nigeria $0 \%$ rate of coinfection was observed, as their study comprised mainly of blood donors [12].

Study from Iran showed very high $72 \%$ rate of coinfection [13]. However, in India, study by Mahajan.A et al showed $0 \%$ coinfection of $\mathrm{HCV}$ with HIV [14] while another study from North India by Tripathi AK etal observed $1.6 \%$ coinfection rate of HCV and HIV [15]. Seroprevalence in the present study is much lower than the result obtained in study performed by Ahuja et al (1.7\%). Another study from Iran showed much higher (72\%) coinfection rate of HIV $\& \mathrm{HCV}[13]$ as these patients were mainly intravenous drug users.

Thus, various studies show that coinfection rates of HCV in HIV infected patients are variable worldwide depending on geographical region, risk groups, and also the type of exposure as seen in various studies. In India also HCV coinfection in HIV patients varies from area to area and varies from $0-8 \%$ [16]. The higher prevalence rate of HCV in HIV positive patients could be considered as noticeable and it could be attributed to diverse factors particularly lack of vaccine for $\mathrm{HCV}$. 


\section{Original Research Article}

Also it is transmitted mostly via injection (especially in drug addiction) because of the increasing rate of addiction in certain countries [13]. It is found that HIV and HCV coinfection is higher in sexually active age group than other age groups. The present study reveals that male patients are mainly coinfected $89.4 \%$ (17/19), while the results by Kalyani et al differs which shows female predominance in their study [3]. The coinfection $\mathrm{HCV}$ with HIV is because of immunological suppression of control of HCV leading to more severe hepatitis C infection [15]. CTL \& helper T cells are responsible for control of $\mathrm{HCV}$ infection. But loss of these cells in HIV infection can lead to $\mathrm{HCV}$ viremia [14].

$\mathrm{HCV}$ antibodies testing alone is not adequate to diagnose chronic $\mathrm{HCV}$ infection as some patients spontaneously clear the virus without treatment but remain $\mathrm{HCV}$ positive. In such patients $\mathrm{HCV}$ viral load (HCV RNA) test is necessary. Also, it is noted that spontaneous viral clearance is less likely to occur among HIV positive patients.

\section{Conclusion}

$\mathrm{HCV}$ coinfection in HIV patients is of serious concern in India. The knowledge of HCV coinfection in patients with HIV is important as the life expectancy of these patients is prolonged with ART and they need to be managed for HCV coinfection simultaneously. Routine screening of these HCV should be mandatory for HIV infected patients as there is increased chance of coinfection with hepatitis viruses because of same route of transmission and immunosuppression of such patients.

\section{What the study adds to the existing knowledge?}

The present study underlines the necessity of a uniform guideline in which all the patients infected with HIV should be screened for HCV to help the management of co infection.

Funding: Nil; Conflict of Interest: None initiated Permission from IRB: Yes

\section{References}

1. Jain M, Chakravarti A, Verma V, Bhalla P. Seroprevalence of hepatitis viruses in patients infected with the human immunodeficiency virus. Indian $\mathbf{J}$ Pathol Microbiol. 2009;52(1):17-19.

2. Chung RT. Hepatitis $C$ and B viruses: the new opportunists in HIV infection. Top HIV Med. 2006; 14 (2): 78-83.
3. Kalyani CS, Lakshmi N, Lakshmi KR, Kumar VA, Cheemala SS. Seroprevalence of hepatitis B virus and hepatitis $\mathrm{C}$ virus co-infection in human immunodeficiency virus infected patients at a tertiary care hospital in South India. International J Res Med Sci. 2015; 3(8):2041-2045. doi: http://dx.doi.org/10. 18203/ 2320-6012.ijrms20150324

4. National Technical Guidelines on Antiretroviral Treatment, October2018, NACO;88.

5. Infographics, Global prevalence of Hiv-Hcv coinfection : 28 MARCH 2019.

6. HIV and AIDS in India, Available at https://www. avert. org/ professionals/hiv-around-world/asia-pacific/ india

7. Barman B, Bora K, Lynrah KG, Lyngdoh WV, Jamil M. Hepatitis $\mathrm{C}$ virus and its genotypes in chronic liver disease patients from Meghalaya, Northeast India. Indian J Med Microbiol. 2018;36(3):376-380. doi: 10. 4103/ijmm.IJMM_17_371.

8. Ponamgi SP, Rahamathulla S, Kumar YN, Chandra M, Lakshmi N, Habibullah CM, et al. Prevalence of hepatitis $\mathrm{C}$ virus (HCV) coinfection in HIV infected individuals in south India and characterization of $\mathrm{HCV}$ genotypes. Indian J Med Microbiol. 2009; 27 (1): 12-16.

9. Adewole OO, Anteyi E, Ajuwon Z, Wada I, Elegba $\mathrm{F}$, Ahmed $\mathrm{P}$, et al. Hepatitis $\mathrm{B}$ and $\mathrm{C}$ virus co-infection in Nigerian patients with HIV infection. J Infect Dev Ctries. 2009;3(5):369-375. doi: 10.3855/jidc.245.

10. Sungkanuparph S, Vibhagool A, Manosuthi W, Kiertiburanakul S, Atamasirikul K, Aumkhyan A, et al. Prevalence of hepatitis B virus and hepatitis C virus coinfection with human immunodeficiency virus in Thai patients: a tertiary-care-based study. J Med Assoc Thai. 2004; 87(11):1349-1354.

11. Saravanan S, Velu V, Kumarasamy N, Nandakumar $\mathrm{S}$, Murugavel KG, Balakrishnan $\mathrm{P}$, et al. Coinfection of hepatitis $\mathrm{B}$ and hepatitis $\mathrm{C}$ virus in HIV-infected patients in south India. World J Gastroenterol. 2007; 13(37): 5015-5120. doi: 10.3748/ wjg. v13.i37. 5015 .

12. Egah DZ, Banwat EB, Audu ES, Iya D, Mandong BM, Anele AA, Gomwalk NE. Hepatitis B surface antigen, hepatitis $\mathrm{C}$ and HIV antibodies in a low-risk blood donor group, Nigeria. East Mediterr Health J. 2007; 13 (4): 961-966.

Pathology Update: Tropical Journal of Pathology \& Microbiology Available online at: www.pathologyreview.in 620 | P a g e 


\section{Original Research Article}

13. Mohammadi M, Talei G, Sheikhian A, Ebrahimzade F, Pournia Y, Ghasemi E, et al. Survey of both hepatitis $\mathrm{B}$ virus ( $\mathrm{HBsAg}$ ) and hepatitis $\mathrm{C}$ virus (HCV-Ab) coinfection among HIV positive patients. Virol J. 2009; 6 (1):202. doi: 10.1186/1743-422X-6-202.

14. Mahajan A, Tandon VR, Verma S, Singh JB, Sharma M. Indian J Med Microbiol. 2008;26(2):196197. doi: 10.4103/0255-0857.40544.

15. Tripathi AK, Khanna M, Gupta N, Chandra M. Low prevalence of hepatitis $\mathrm{B}$ virus and hepatitis $\mathrm{C}$ virus coinfection in patients with human immunodeficiency virus in Northern India. JAPI. 2007;55:429-431.

16. Tankhiwale SS, Khadase RK, Jalgoankar SV. Seroprevalence of anti-HCV and hepatitis B surface antigen in HIV infected patients. Indian $\mathrm{J}$ Med Microbiol. 2003;21(4):268-270.

\section{How to cite this article?}

Kaur C. Seroprevalence of HIV \& HCV coinfection among patients in a rural tertiary care centre in North India. Trop J Path Micro 2018;4(8):617-621.doi: 10.17511/jopm.2018.i08.12. 